\title{
Liquidity Ratio: An Important Financial Metrics
}

\author{
B.N. Lalithchandra ${ }^{a}$, and Dr. N. Rajendhiran ${ }^{b}$ \\ Research Scholar \\ ${ }^{\mathbf{b}}$ Retd. Professor and Director, \\ Department of Management Studies, \\ Periyar University, Salem
}

Article History: Received: 11 January 2021; Accepted: 27 February 2021; Published online: 5 April 2021

\begin{abstract}
The world of business has become an important criterion for survival these days. In the context of the realm of business, the liquidity ratio plays an imperative role in all possible ways. It has become the obligatory criteria in analyzing the liquidity ratio for a better understanding of the world of business nuances in general and the status of the company in particular. Analyzing the liquidity ratio guides in taking a bold and smart decision which will, in turn, seek the attention of prospective investors. It is highly essential for small-scale business developers to have a proper analysis of the liquidity ratio for better growth progress. This paper tries to investigate the needs of the liquidity ratio analysis from a business perspective.
\end{abstract}

Keywords: Liquidity Ratio, Small-Scale Business, Cash Flow, Liability, Asset, the Capital

\section{Introduction}

In a view of a business, liquidity refers to the ability of a company in raising the cash flow. The debt capacity and the ability in converting the assets to cash are the major determiners in tracing the liquidity of a company. Cash flow is considered the most liquid of all assets. Business liquidity is determined by the efficiency in converting the asset of a company into cash flow.

\section{Objectives}

To understand the importance of the liquidity ratio of a company

To understand the difference between various liquidity ratios

\section{Liquidity analysis - Need of business}

Liquidity ratio analysis helps to identify the ability of the company in paying its bill in due course of time.This analysis is important both for lenders and creditors. The simple and easiest way in measuring the Liquidity can be the current ratio.

\section{Current Ratio $=$ Current Assets / Current Liabilities}

The current ratio of liquidity can be calculated by dividing the current asset by current liabilities. The liquidity ratio helps in measuring the ability of a company's capacity in paying its debt. In addition, the efficiency of the company's payment of its short-term liabilities can be understood clearly by calculating the liquidity of a company. If the current ratio is higher it indicates the higher liquidity ratio. If the company shows its current ratio to be one or higher, it is a good sign indicator. Whereas, it is the indication of the company's ability in paying its short-term liabilities. If a company shows a value ratio - anything higher than the value of one - is considered a good sign. It, in turn, indicates the wealth of a company's financial status and its position in liabilities to the limelight. A company which shows a good liquidity ratio seldom show the sign of financial hardships.

Liquidity management is an essential managerial skill required in any business sector. Managing the cash obligations of a company and intelligent maintenance of the finance without experiencing the significant loss are the most essential factors of managerial skill in recent days. The power of the company during its tough time can be well understood by calculating the liquidity of the company. The main reasons behind calculating the liquidity of the company are to know:

The company's ability in paying its debt during its tough time.

The ability in meeting its short-term obligations.

The survival capacity of the firm during its hard financial time.

The working capital analysis

Working capital is also known as networking capital. The working capital analysis will help in finding out the readiness of the company in meeting its immediate requirements regarding the financial status. The working capital can be calculated by the formula,

Working capital $=$ current assets - current liabilities

$\mathrm{WC}=\mathrm{CA}-\mathrm{CL}$

This fundamental analysis helps in calculating the liquidity of the company. Thus working capital or networking capital is a measurement of a company's liquidity, efficiency, etc. working capital management is an essential task because it measures the relationship of an entity in terms of its short-term assets and its liabilities. 
Depending on the debt of the company, the end result of networking capital may vary in positive or negative values. Positive working capital is always a good sign, which indicates the positive and healthy indication of the company in its ability to repay its short-term liabilities. Further, they can expand their operation by showing their healthy sign. Whereas, the negative working capital indicates the struggle of the company

\section{Acid test ratio}

This analysis helps in measuring the liquidity of current assets. A certain category of items cannot be converted into the liquidity of cash flow of the company, in such case, analysis of acid test ratio helps in finding out the liquidity of the company. Acid test ratio in other terms quick ratio helps in finding out the liquidity of current assets effectively. Thus in calculating the quick ratio, the inventory - the least liquid assets - is excluded from the current assets. So quick ratio can be calculated effectively using the formula,

Quick ratio $=$ (Current asset- Inventory) / current liability

Quick ratio $=(\mathrm{CA}-$ Inventory $) / \mathrm{CL}$

The average of 2.1 indicates the good liquidity flow of the company.

The company's liquidity position can also be analysed by comparing its stock price to the amount of cash per share. K. H. I. Madushanka and M. Jathurika. (2018, p. 157) state their view on liquidity ratio and its importance as

The ultimate goal of the companies is to enhance the wealth of the shareholders. For that purpose the liquidity and profitability plays the vital and crucial role. Especially the liquidity and its management are caused to great extent of the growth and profitability of a firm. The liquidity management becomes most important one as the inadequate liquidity may injurious to the smooth operations of the firm as well as the excess liquidity can be disturbed to achieve the greater profits

Analysing the liquidity ratio will help the smooth flow of business with the proper cash flow maintenance. This will indeed aid in continuous business operation and development and growth progress.

\section{Conclusion}

Various techniques can be adopted for increasing the liquidity flow of the company for the betterment of profit. Some of the techniques which promote a better business can be adopted to increase the flow of money. Transferring the cash into an interesting bearing account when the money is not needed. Finding and reducing the overhead cost to escalate productivity. It could can the advertising of the firm, indirect labour charges, transport allowances, etc. Investing on the required assets will also reduce unwanted money flow. Proper monitoring of the cash flow both in and out. Prompt billing and receiving the payments will enhance the smooth flow of business. Intelligent negotiation of the long-term cash payment will enhance the money flow in the company. Analysing the market status to increase the profitability from time to time will effectively help in good money flow.

\section{References}

1. Ashraf C K., (2012), The relationship between working capital efficiency and profitability, Journal of accounting and management, Vol. 2, Iss. 3, pp 45-49.

2. Bolek, Monika and Rafal Wolski. (2012),Profitability or Liquidity: Influencing the Market Value The Case of Poland, International Journal of Economics and Finance; Vol. 4, Iss. 9, pp. 182-190.

3. K. H. I. Madushanka and M. Jathurika. (2018), The Impact of Liquidity Ratios on Profitability, International Research Journal of Advanced Engineering and Science, Vol. 3, Iss. 4, pp. 157-161.

4. Kumar, A.V., and Venkatachalam, A., (1995), Working capital \& profitability-An empirical analysis. The management accountant, Vol. 30, Iss. 10, pp. 748-750.

5. Panigrahi. A.K (2014), Relationship of working capital with liquidity, Profitability and solvency: A case study of ACC limited, ASIAN JOURNAL OF MANAGEMENT RESEARCH, Vol. 4, Iss.2, pp. 208-322. 